\title{
Tuning Parameter Linear Quadratic Tracking Menggunakan Algoritma Genetika untuk Pengendalian Gerak Lateral Quadcopter
}

\author{
Farid Choirul Akbar, Rushdianto Effendie A. K., dan Eka Iskandar \\ Jurusan Teknik Elektro, Fakultas Teknologi Industri, Institut Teknologi Sepuluh Nopember (ITS) \\ Jl. Arief Rahman Hakim, Surabaya 60111 \\ E-mail: faridchoiru192@gmail.com,rusdhi@elect-eng.its.ac.id, iskandar@elect-eng.its.ac.id
}

\begin{abstract}
Abstrak-Gerakan lateral quadcopter dapat dilakukan apabila quadcopter dapat menjaga kestabilan pada saat hover, sehingga quadcopter dapat melakukan gerak rotasi. Perubahan sudut roll akan mengakibatkan gerak translasi pada sumbu $Y$, sedangkan perubahan sudut pitch akan mengakibatkan gerak translasi pada sumbu X. Disisi lain, quadcopter merupakan suatu sistem non-linear dan memiliki kestabilan yang rendah sehingga rentan terhadap gangguan. Pada penelitian Tugas Akhir ini dirancang pengendalian gerak rotasi quadcopter menggunakan Linear Quadratic Regulator (LQR) dan Linear Quadratic Tracking (LQT) untuk pengendalian gerak translasi. Untuk mendapatkan parameter dari LQT digunakan Algoritma Genetika (GA). Hasil tuning GA yang digunakan pada LQT memiliki nilai Qx 700,1884, nilai $Q y$ 700,6315, nilai $R x$ 0,1568, dan nilai $R y$ 0,1579. Respon LQT tersebut memiliki RMSE pada sumbu $X$ dan sumbu $Y$ sebesar $1,99 \%$ serta memiliki time lagging 0,35 detik. Dengan hasil tersebut quadcopter mampu men-tracking trajectory berbentuk segitiga.
\end{abstract}

Kata Kunci-Quadcopter, lateral, Linear Quadratic Regulator, Linear Quadratic Tracking, Algoritma Genetika

\section{PENDAHULUAN}

$\mathbf{P}$ ADA saat ini, teknologi bidang penerbangan berkembang dengan pesat. Salah satu contohnya ialah Unmanned Aerial Vehicle (UAV) atau pesawat tanpa awak. UAV banyak mendapat perhatian dari berbagai kalangan, karena dapat menggantikan peran pilot manusia sebagai sistem kendalinya. Hal tersebut menjadikan UAV banyak dimanfaatkan untuk keperluan militer ataupun sipil [1].

Salah satu contoh UAV adalah Quadcopter memiliki dua macam gerakan, yaitu gerak rotasi dan gerak translasi. Gerak rotasi merupakan gerakan yang terjadi pada poros quadcopter dimana terdiri dari gerak roll, pitch, dan yaw. Sedangkan gerak translasi merupakan gerakan yang dihasilkan akibat adanya gerak rotasi. Gerakan ini dibagi menjadi dua, yaitu gerak lateral dan gerak longitudinal. Gerak longitudinal meliputi tiga fase utama, yaitu take-off (tinggal landas), hovering (melayang), dan landing (pendaratan), sedangkan gerak lateral mencakup gerakan dari satu titik ke titik lain secara horisontal (waypoint)[2].

Gerakan lateral quadcopter dapat dilakukan apabila quadcopter dapat menjaga kestabilan saat melakukan hover, karena gerak ini terjadi akibat adanya perubahan sudut dari gerak rotasi quadcopter. Perubahan sudut roll akan mengakibatkan gerak translasi pada sumbu $\mathrm{Y}$, sedangkan perubahan sudut pitch akan mengakibatkan gerak translasi pada sumbu X. Sehingga untuk melakukan gerakan lateral quadcopter, harus dilakukan gerak rotasi terlebih dahulu.

Disisi lain, quadcopter merupakan suatu sistem nonlinear dan memiliki kestabilan yang rendah sehingga rentan terhadap gangguan. Untuk itu perlu suatu pengendalian yang dapat menjaga kestabilan quadcopter ketika mekaukan gerak rotasi maupun ketika melakukan gerak translasi. Pada penelitian yang sudah ada, banyak digunakan metode kontrol konvensional PI, PID, Linear Quadratic Control, dan lainlain [3]. Pada penelitian dengan menggunkan Linear Quadratic Control, hasil yang didapatkan cukup baik. Namun penentuan parameternya masih menggunakan metode try and error [3].

Pada penelitian ini akan digunakan metode Linear Quadratic Regulator (LQR) untuk pengendalian gerak rotasi quadcopter. Pada gerak lateral akan digunakan metode Linear Quadratic Tracking (LQT). Nilai gain feedback dan indeks performasi dari LQT bergantung pada kombinasi dari Q dan R. Untuk mendapatkan kombinasi Q dan R dapat digunakan metode tuning manual (try and error). Namun sering kali didapatkan hasil yang tidak optimal. Oleh karena itu pada penelitian ini digunakan metode Algoritma Genetika (GA) untuk menggantikan metode tuning manual.

\section{TEORI PENUNJANG}

\section{A. Quadcopter [2].}

Quadcopter yang digunakan sebagai robot terbang kecil memiliki model mekanik yang terdiri dari empat rotor yang dipasang pada sumbu plus (+) simetris. Bentuk ini diharapkan tipis dan kaku, sehingga diperoleh friksi udara yang kecil dan komponen yang bergerak pada quadcopter hanyalah putaran propeller. Setiap propeller pada quadcopter diputar oleh satu motor elektrik, sehingga terdapat empat motor sebagai aktuator untuk menghasilkan gaya angkat dari quadcopter.

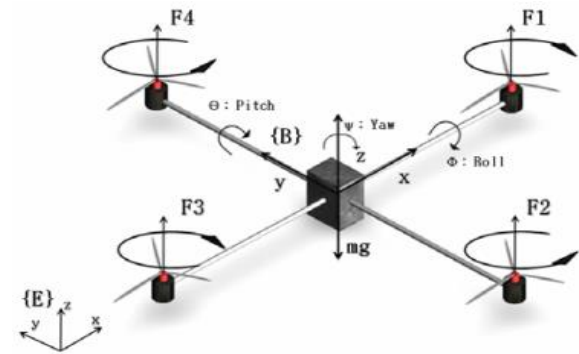

Gambar 1 Konfigurasi Quadcopter dengan Dua Motor Bergerak Searah Jarum Jam dan Dua Motor Bergerak Berlawanan Jarum Jam

Dengan batasan menggunakan karakteristik motor dan propeller yang relatif sama, maka kondisi melayang yang 
stabil akan diperoleh kecepatan motor yang sama ditiap propeller. Konfigurasi propeller terdiri dari dua macam, yaitu dua propeller yang bergerak searah jarum jam dan dua propeller yang bergerak berlawanan arah jarum jam dimana setiap satu sumbu, propeller berputar dengan arah yang sama. Pada Gambar 1, sketsa dari struktur ditunjukkan bahwa terdapat empat input yang terdapat pada quadrotor, yaitu roll, pitch, yaw dan thrust.

\section{B. Linear Quadratic Regulator (LQR)[4]}

LQR merupakan salah satu kontrol optimal dimana mempunyai maksud hasil paling baik yang dapat dicapai dengan memperhatikan kondisi dan kendala dari suatu sistem. Dalam sistem kontrol optimal, istilah optimal sering kali merujuk pada minimal, misalnya meminimalkan bahan bakar (input), waktu, dan kesalahan (error). Kontrol optimal secara umum digunakan untuk memilih input plant $u$ dengan indeks performansi yang minimum.

Pada suatu sistem, indeks performansi dipilih sesuai dengan bagian yang akan dioptimalkan. Bentuk umum dari persamaan state sistem linear ditunjukkan oleh Persamaan (1).

$$
\begin{aligned}
& \dot{x}=A x+B u \\
& y=C x
\end{aligned}
$$

Indeks performansi dari minimum energi (cost function/quadratic function) ditunjukkan oleh Persamaan (2).

$$
J=\frac{1}{2} \int_{0}^{\infty}\left(x^{T} Q+u^{T} R u\right) d t
$$

Persamaan regulator dapat diselesaikan dengan menyelesaikan persamaan aljabar Riccati sesuai dengan Persamaan (3)-(5).

$$
\begin{aligned}
& A^{T} P+P A-P B R^{-1} B^{T} P+Q=0 \\
& -K=R^{-1} B^{T} P \\
& u=-K x
\end{aligned}
$$

\section{Linear Quadratic Tracking [4]}

LQT merupakan sistem pengaturan linear yang output sistem mengikuti referensi (trajectory) yang diinginkan. Suatu sistem mempunyai persamaan state (1) dan vektor kesalahan seperti Persamaan (6). Indeks performansi didefinisikan pada Persamaan (7).

$$
\begin{aligned}
& e=z-y \\
& J=\frac{1}{2} e^{\prime}\left(t_{f}\right) F\left(t_{f}\right) e\left(t_{f}\right)+\frac{1}{2} \int_{t_{0}}^{t_{f}}\left[e^{\prime} Q e+u^{\prime} R u\right] d t
\end{aligned}
$$

Setelah mendapatkan model matematika sistem dalam bentuk state-space, matriks penyelesaian persamaan differential Riccati dapat didapatkan dengan Persamaan (8) untuk infinite-time case.

$$
0=-P A-A^{\prime} P+P B R^{-1} B^{\prime} P+C^{\prime} Q C
$$

Matriks $\mathrm{Q}$ dan $\mathrm{R}$ dapat diasumsikan sesuai dengan performansi yang diinginkan sistem. Setelah mendapatkan persamaan Riccati, persamaan diferensial vektor nonhomogen dapat dicari menggunakan Persamaan (9).

$$
\dot{g}=-\left[A-B R^{-1} B^{\prime} P\right]^{\prime} g-C^{\prime} Q z
$$

Setelah mendapatkan matriks $P$ yang merupakan matriks definit positif yang simetris dan $g$, nilai gain feedback $K$ dapat dicari dengan menggunakan Persamaan (10).

$$
K=R^{-1} B^{\prime} P
$$

\section{Algoritma Genetika [5][6]}

Pada bidang kontrol, GA dapat digunakan untuk meningkatkan performansi sistem. Salah satunya ialah pada metode Linear Quadratic Tracking (LQT). Tujuan dari metode LQT ialah untuk memperoleh aksi kontrol optimal yang meminimalisasi indeks performansi dan memerintahkan plant agar dapat melakukan tracking sesuai dengan model (trajectory) yang telah ditentukan. Untuk mendapatkan aksi kontrol yang optimal bergantung pada besarnya nilai Q dan R. Nilai Q dan R didapatkan dengan hasil tuning manual (try and error).

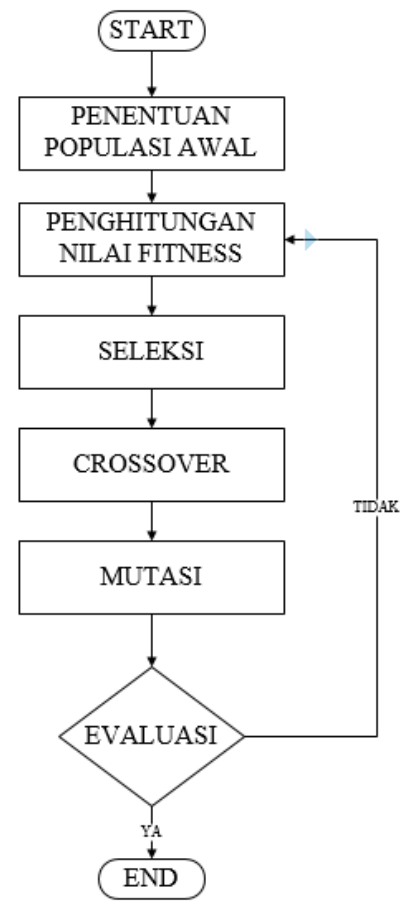

Gambar 2 Flowchart Proses GA

Metode tuning try and error sering kali didapatkan hasil kontrol yang tidak optimal. Untuk mendapatkan kombinasi nilai $\mathrm{Q}$ dan $\mathrm{R}$ digunakan metode tuning menggunakan GA. Setelah didapatkan nilai $\mathrm{Q}$ dan $\mathrm{R}$ yang optimal, maka akan didapatkan nilai gain feedback yang optimal sehingga didapatkan hasil desain yang optimal. Flowchart pada proses GA ditunjukkan pada Gambar 2.

\section{PEMODELAN DAN PERANCANGAN}




\section{A. Model Matematika Quadcopter}

Persamaan model matematika quadcopter diperoleh dari analisis kinematika dan dinamika pada buku [2] [3] dinyatakan pada Persamaan (11)-(16)

$$
\begin{aligned}
& \ddot{X}=(\sin \psi \sin \theta+\cos \psi \sin \theta \cos \phi) \frac{U_{1}}{m} \\
& \ddot{Y}=(-\cos \psi \sin \phi+\sin \psi \sin \theta \cos \phi) \frac{U_{1}}{m} \\
& \ddot{Z}=-g+(\cos \theta \cos \phi) \frac{U_{1}}{m} \\
& \dot{p}=\frac{I_{X X}-I_{Y Y}}{I_{X X}} q r-\frac{J_{T P}}{I_{X X}} q \Omega+\frac{U_{2}}{I_{X X}} \\
& \dot{q}=\frac{I_{Z Z}-I_{X X}}{I_{Y Y}} p r+\frac{J_{T P}}{I_{Y Y}} p \Omega+\frac{U_{3}}{I_{Y Y}} \\
& \dot{r}=\frac{I_{X X}-I_{Y Y}}{I_{Z Z}} p q+\frac{U_{4}}{I_{Z Z}}
\end{aligned}
$$

Sinyal kontrol (torsi) yang digunakan untuk melakukan gaya thrust, gerakan sudut roll, pitch, dan yaw didefinisikan sebagai penjumlahan kuadarat dari setiap motor. Hubungan dari setiap kecepatan motor untuk menghasilkan sinyal kontrol (torsi) terdapat pada dalam Persamaan (17)-(21).

$$
\begin{aligned}
& U_{1}=b\left(\Omega_{1}^{2}+\Omega_{2}^{2}+\Omega_{3}^{2}+\Omega_{4}^{2}\right) \\
& U_{2}=l b\left(-\Omega_{2}^{2}+\Omega_{4}^{2}\right) \\
& U_{3}=l b\left(-\Omega_{1}^{2}+\Omega_{3}^{2}\right) \\
& U_{4}=d\left(-\Omega_{1}^{2}+\Omega_{2}^{2}-\Omega_{3}^{2}+\Omega_{4}^{2}\right) \\
& \Omega=-\Omega_{1}+\Omega_{2}-\Omega_{3}+\Omega_{4}
\end{aligned}
$$

Parameter hasil pengukuran terdapat pada Tabel 1.

Tabel 1 Parameter Quadcopter Hasil Pengukuran

\begin{tabular}{|c|l|r|r|}
\hline No & \multicolumn{1}{|c|}{ Parameter } & \multicolumn{1}{|c|}{ Nilai } & Satuan \\
\hline 1 & Massa quadcopter $(m)$ & 1,26 & $\mathrm{~kg}$ \\
\hline 2 & Jari-jari quadcopter $(l)$ & 0,206 & Meter \\
\hline 3 & Gravitasi $(g)$ & 9,81 & $\mathrm{~N} / \mathrm{m}^{2}$ \\
\hline 4 & Konstanta Thrust & $1,6898 \times 10^{-5}$ & $\mathrm{~N} \mathrm{~s}^{2}$ \\
\hline 5 & Konstanta Drag & $4,19 \times 10^{-6}$ & $\mathrm{Nms}^{2}$ \\
\hline
\end{tabular}

Pada Persamaan (14)-(16) terdapat variabel dari model matematika untuk gerak rotasi quadcopter yang belum diketahui. Pada penelitian ini digunakan identifikasi parametrik dengan data penerbangan quadcopter. Persamaan (14)-(16) dimodifikasi menjadi Persamaan (21)-(23).

$$
\begin{aligned}
& \dot{p}=a_{1} q r+b_{1} q \Omega+c_{1} U_{2} \\
& \dot{q}=a_{2} p r+b_{2} p \Omega+c_{2} U_{3} \\
& \dot{r}=a_{3} p q+b_{3} U_{4}
\end{aligned}
$$

Dari data hasil penerbangan didapatkan model matematika quadcopter pada Persamaan (24)-(26).

$$
\begin{aligned}
& \dot{p}=-0,5495 q r-0,0017 q \Omega+0,2052 U_{2} \\
& \dot{q}=0,16775 p r-0,0094 p \Omega+2,955 U_{3} \\
& \dot{r}=-2,0257 p q+0,0594 U_{4}
\end{aligned}
$$

\section{B. Perancangan Kontroler Gerak Rotasi}

Pada penelitian ini perancangan gerak rotasi menggunaknakan LQR. Langkah pertama ialah mendefinisikan hubungan linear antar variabel. Hubungan linear tersebut ditunjukkan pada Persamaan (27)-(29)

$$
\begin{aligned}
& \dot{\phi}=p, \ddot{\phi}=\dot{p} \\
& \dot{\theta}=q, \ddot{\theta}=\dot{q} \\
& \dot{\psi}=r, \ddot{\psi}=\dot{r}
\end{aligned}
$$

Untuk membuat state space dari LQR pengendalian sudut roll, Persamaan (21) harus dimodifikasi pada Persamaan (30)-(35).

$$
\begin{aligned}
& \ddot{\phi}=c_{1} U_{2}+a_{1} q r+b_{1} q \Omega \\
& \ddot{\phi}=c_{1}\left(U_{2}+\frac{1}{c_{1}}\left(a_{1} q r+b_{1} q \Omega\right)\right) \\
& U_{2}^{*}=U_{2}+\frac{1}{c_{1}}\left(a_{1} q r+b_{1} q \Omega\right) \\
& \ddot{\phi}=c_{1} U_{2}^{*} \\
& {\left[\begin{array}{l}
\dot{\phi} \\
\ddot{\phi}
\end{array}\right]=\left[\begin{array}{ll}
0 & 1 \\
0 & 0
\end{array}\right]\left[\begin{array}{l}
\phi \\
\dot{\phi}
\end{array}\right]+\left[\begin{array}{c}
0 \\
c_{1}
\end{array}\right] U_{2}^{*}} \\
& Y=\left[\begin{array}{ll}
1 & 0
\end{array}\right]\left[\begin{array}{l}
\phi \\
\dot{\phi}
\end{array}\right]
\end{aligned}
$$

Sedangkan untuk sudut pitch Persamaan (22) harus dimodifikasi pada Persamaan (36)-(41).

$$
\begin{aligned}
& \ddot{\theta}=c_{2} U_{3}+a_{2} p r+b_{2} p \Omega \\
& \ddot{\theta}=c_{2}\left(U_{3}+\frac{1}{c_{2}}\left(a_{2} p r+b_{2} p \Omega\right)\right) \\
& U_{3}^{*}=U_{3}+\frac{1}{c_{2}}\left(a_{2} p r+b_{2} p \Omega\right) \\
& \ddot{\theta}=c_{2} U_{3}^{*} \\
& {\left[\begin{array}{c}
\dot{\theta} \\
\ddot{\theta}
\end{array}\right]=\left[\begin{array}{ll}
0 & 1 \\
0 & 0
\end{array}\right]\left[\begin{array}{c}
\theta \\
\dot{\theta}
\end{array}\right]+\left[\begin{array}{c}
0 \\
c_{2}
\end{array}\right] U_{3}^{*}} \\
& Y=\left[\begin{array}{ll}
1 & 0
\end{array}\right]\left[\begin{array}{l}
\theta \\
\dot{\theta}
\end{array}\right]
\end{aligned}
$$

Untuk perancangan sudut yaw Persamaan (23) harus dimodifikasi pada Persamaan (42)-(47)

$$
\begin{aligned}
& \ddot{\psi}=b_{3} U_{4}+a_{3} p q \\
& \ddot{\psi}=b_{3}\left(U_{4}+\frac{1}{b_{3}}\left(a_{3} p q\right)\right) \\
& U_{4}^{*}=U_{4}+\frac{1}{b_{3}}\left(a_{3} p q\right) \\
& \ddot{\psi}=b_{3} U_{4}^{*} \\
& {\left[\begin{array}{l}
\dot{\psi} \\
\ddot{\psi}
\end{array}\right]=\left[\begin{array}{ll}
0 & 1 \\
0 & 0
\end{array}\right]\left[\begin{array}{l}
\psi \\
\dot{\psi}
\end{array}\right]+\left[\begin{array}{c}
0 \\
b_{3}
\end{array}\right] U_{4}^{*}}
\end{aligned}
$$




$$
Y=\left[\begin{array}{ll}
1 & 0
\end{array}\right]\left[\begin{array}{l}
\psi \\
\dot{\psi}
\end{array}\right]
$$

Untuk mendapatkan gain feedback dari LQR digunakan tuning manual (try and error) pada Tabel 2.

Tabel 2 Nilai Q dan R LQR Pengendalian Gerak Rotasi

\begin{tabular}{|c|c|c|c|}
\hline No & Parameter & Nilai & $\mathbf{K}$ \\
\hline & Q Roll & {$\left[\begin{array}{ll}1000 & 0\end{array}\right]$} & \multirow{3}{*}[\begin{array}{ll}{10^{4}}&{0.044}\end{array}]{} \\
\hline & & $\begin{array}{ll}0 & 1\end{array}$ & \\
\hline & $\mathrm{R}$ Roll & 0.00001 & \\
\hline \multirow[t]{3}{*}{2} & Q Pitch & {$\left[\begin{array}{ll}1000 & 0\end{array}\right]$} & \multirow{3}{*}[\begin{array}{ll}{100}&{10.3764}\end{array}]{} \\
\hline & & $\left.\begin{array}{ll}0 & 4\end{array}\right]$ & \\
\hline & R Pitch & 0.1 & \\
\hline \multirow[t]{3}{*}{3} & Q Yaw & {$\left[\begin{array}{ll}1000 & 0\end{array}\right]$} & \multirow{3}{*}[\begin{array}{ll}{3.162\times10^{3}}&{0.3827}\end{array}]{} \\
\hline & & {$\left[\begin{array}{ll}0 & 4\end{array}\right]$} & \\
\hline & R Yaw & 0.00001 & \\
\hline
\end{tabular}

\section{Perancangan Kontroler Gerak Translasi}

Gerak translasi merupakan gerakan yang diakibatkan karena adanya gerak rotasi. Sehingga pada gerak translasi sumbu X dan sumbu Y, digunakan metode kontrol cascade dimana sinyal kontrol dari kontroler translasi menjadi set point (referensi) untuk kontroler rotasi. Untuk pengendalian sumbu Z, tidak memerlukan gerak rotasi karena tidak bergantung pada perubahan sudut quadcopter.

Perancangan gerak translasi quadcopter digunakan pendekatan bahwa quadcopter bersifat rigit untuk sudut yaw sehingga besarnya perubahan sudut yaw bernilai sangat kecil (mendekati nol). Oleh karena itu model matematika gerak translasi sumbu X pada Persamaan (11) akan menjadi Persamaan (48).

$$
\ddot{X}=(\sin \theta \cos \phi) \frac{U_{1}}{m}
$$

Untuk meghilangkan efek nonlinear dari model, digunakan modifikasi pada Persamaan (49)-(52).

$$
\begin{aligned}
& U_{x}^{*}=(\sin \theta \cos \phi) \frac{U_{1}}{m} \\
& \ddot{X}=U_{x}^{*} \\
& {\left[\begin{array}{c}
\dot{X} \\
\ddot{X}
\end{array}\right]=\left[\begin{array}{ll}
0 & 1 \\
0 & 0
\end{array}\right]\left[\begin{array}{c}
X \\
\dot{X}
\end{array}\right]+\left[\begin{array}{l}
0 \\
1
\end{array}\right] U_{x}^{*}} \\
& Y=\left[\begin{array}{ll}
1 & 0
\end{array}\right]\left[\begin{array}{c}
X \\
\dot{X}
\end{array}\right]
\end{aligned}
$$

Sinyal kontrol LQT merupakan $\theta r e f$ maka dilakukan konversi sinyal kontrol $U_{x}{ }^{*}$ menjadi $\theta$ pada Persamaan (53)(54).

$$
\begin{aligned}
& \sin \theta=\frac{m U_{x}^{*}}{U_{1} \cos \phi} \\
& \theta=\arcsin \left(\frac{m U_{x}^{*}}{U_{1} \cos \phi}\right)
\end{aligned}
$$

Pada pengendalian gerak translasi sumbu $\mathrm{Y}$ sama seperti sumbu X, dimana Persamaan (12) akan menjadi Persamaan (55)

$$
\ddot{Y}=(-\sin \phi) \frac{U_{1}}{m}
$$

Untuk meghilangkan efek nonlinear dari model, digunakan modifikasi pada Persamaan (56)-(59).

$$
\begin{aligned}
& U_{y}^{*}=(-\sin \phi) \frac{U_{1}}{1.26} \\
& \ddot{Y}=U_{y}^{*} \\
& {\left[\begin{array}{c}
\dot{Y} \\
\ddot{Y}
\end{array}\right]=\left[\begin{array}{ll}
0 & 1 \\
0 & 0
\end{array}\right]\left[\begin{array}{l}
Y \\
\dot{Y}
\end{array}\right]+\left[\begin{array}{l}
0 \\
1
\end{array}\right] U_{y}^{*}} \\
& Y=\left[\begin{array}{ll}
1 & 0
\end{array}\right]\left[\begin{array}{c}
Y \\
\dot{Y}
\end{array}\right]
\end{aligned}
$$

Sinyal kontrol LQT merupakan $\phi r e f$ maka dilakukan konversi sinyal kontrol $U_{y}{ }^{*}$ menjadi $\phi$ pada Persamaan (60)(61).

$$
\begin{aligned}
& \sin \phi=\frac{(-1.26) U_{y}^{*}}{U_{1}} \\
& \phi=\arcsin \left(\frac{(-1.26) U_{y}^{*}}{U_{1}}\right)
\end{aligned}
$$

Pada perancangan gerak sumbu $Z$, Persamaan (13) harus dimodifikasi pada Persamaan (62)-(66)

$$
\begin{aligned}
& \ddot{Z}=-g+(\cos \theta \cos \phi) \frac{U_{1}}{m} \\
& U_{1}^{*}=-g+(\cos \theta \cos \phi) \frac{U_{1}}{m} \\
& \ddot{Z}=U_{1}^{*} \\
& {\left[\begin{array}{c}
\dot{Z} \\
\ddot{Z}
\end{array}\right]=\left[\begin{array}{ll}
0 & 1 \\
0 & 0
\end{array}\right]\left[\begin{array}{l}
Z \\
\dot{Z}
\end{array}\right]+\left[\begin{array}{l}
0 \\
1
\end{array}\right] U_{1}^{*}} \\
& Y=\left[\begin{array}{ll}
1 & 0
\end{array}\right]\left[\begin{array}{l}
Z \\
\dot{Z}
\end{array}\right]
\end{aligned}
$$

Pada penelitian ini, pengendalian gerak translasi dengan tuning GA dibatasi hanya pada oengendalian gerak translasi sumbu $\mathrm{X}$ dan sumbu $\mathrm{Y}$. Untuk sumbu $\mathrm{Z}$ digunakan metode tuning try and error pada Tabel 3

Tabel 3 Nilai Q dan R LQT Pengendalian Quadcopter pada Sumbu Z

\begin{tabular}{|c|l|r|}
\hline No & Parameter & Nilai \\
\hline 1 & $\mathrm{Qz}$ & 1000 \\
\hline 2 & $\mathrm{Rz}$ & 0.0001 \\
\hline
\end{tabular}

\section{Perancangan Algoritma Genetika (GA)}

Perancangan GA didefinisikan individu Q dan R pada sebuah populasi seperti pada Gambar 3. Nilai fitness yang digunakan ditunjukkan pada Persamaan (66). 


\section{\begin{tabular}{l|l|l|l}
$\mathbf{Q x}$ & $\mathbf{Q y}$ & $\mathbf{R x}$ & $\mathbf{R y}$
\end{tabular}}

Gambar 3 Perancangan Individu GA

$$
f=\frac{1}{I P x * 0.2+R M S E x * 0.3+I P y * 0.2+R M S E y * 0.3}
$$

Seleksi pada individu digunakan untuk memilih kromosom yang memiliki nilai fitness tinggi. Seleksi yang digunakan terdiri dari 2 macam, yaitu truncking dan mesin roullete. Seleksi truncking digunakan untuk memilih individu yang memiliki nilai fitness tinggi. Banyaknya individu yang hilang bergantung pada besarnya rasio dari seleksi (selection rate). Individu yang tersisa selanjutnya diseleksi secara acak dengan menggunakan mesin roullete.

Crossover dilakukan pada semua individu. Metode yang digunakan ialah dengan membangkitkan nilai random integer yang merepresentasikan nilai cut poin untuk menghasilkan individu baru.

Banyaknya gen yang mengalami mutasi bergantung pada rasio mutasi. Untuk memilih posisi gen yang mengalami mutasi, dibangkitkan nilai random dari banyaknya gen yang mengalami mutasi.

\section{PENGUJIAN DAN ANALISIS}

\section{A. Simulasi Pengujian $L Q R$ dengan Nilai $\mathbf{Q}$ dan $\mathbf{R}$ Berbeda}

Hasil dari pengujian sudut roll dan pitch ditunjukkan pada Gambar 4 dan 5. Sedangkan karakteristik respon tersebut ditunjukkan pada Tabel 4 dan 5.

Tabel 4 Karakteristik Respon Variasi Nilai Q pada LQR Pengendalian Sudut

\begin{tabular}{|c|c|c|c|c|}
\hline $\mathbf{Q}$ & $\mathrm{K}$ & $\tau$ & $t_{s}$ & $t_{r}$ \\
\hline$\left[\begin{array}{cc}10 & 0 \\
0 & 1\end{array}\right]$ & {$\left[\begin{array}{ll}1000 & 331,281\end{array}\right]$} & 0,332 & 0,996 & 0,978 \\
\hline$\left[\begin{array}{cc}100 & 0 \\
0 & 1\end{array}\right]$ & {$\left[\begin{array}{ll}3,162 \times 10^{3} & 0.362\end{array}\right]$} & 0,110 & 0,331 & 0,325 \\
\hline$\left[\begin{array}{cc}1000 & 0 \\
0 & 1\end{array}\right]$ & {$\left[\begin{array}{ll}10^{4} & 0,044]\end{array}\right.$} & 0,048 & 0,146 & 0,143 \\
\hline$\left[\begin{array}{cc}1000 & 0 \\
0 & 4\end{array}\right]$ & {$\left[\begin{array}{ll}10^{4} & 0,071\end{array}\right]$} & 0,073 & 0,219 & 0,214 \\
\hline$\left[\begin{array}{cc}800 & 0 \\
0 & 4\end{array}\right]$ & {$\left[9,94 \times 10^{3} \quad 0,698\right]$} & 0,080 & 0,241 & 0,237 \\
\hline$\left[\begin{array}{cc}500 & 0 \\
0 & 4\end{array}\right]$ & {$\left[7,07 \times 10^{3} \quad 0,685\right]$} & 0,099 & 0,2982 & 0,2927 \\
\hline
\end{tabular}

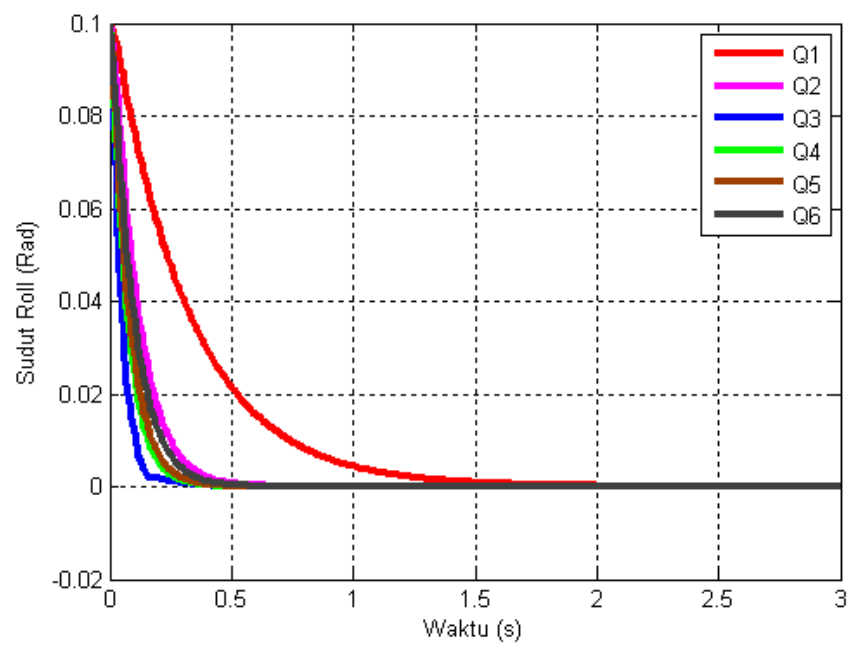

Gambar 4 Respon Variasi Nilai Q pada Pengendalian LQR Sudut Roll

Tabel 5 Karakteristik Respon Variasi Nilai Q pada LQR Pengendalian Sudut Pitch

\begin{tabular}{|c|rr|r|c|c|}
\hline $\mathbf{Q}$ & $\mathbf{K}$ & $\boldsymbol{\tau}$ & $\mathbf{t}_{\mathbf{s}}$ & $\mathbf{t}_{\mathbf{r}}$ \\
\hline$\left[\begin{array}{ll}10 & 0 \\
0 & 1\end{array}\right]$ & {$\left[\begin{array}{ll}10 & 4,095\end{array}\right]$} & 0.428 & 1.284 & 1.26 \\
\hline$\left[\begin{array}{cc}100 & 0 \\
0 & 1\end{array}\right]$ & {$\left[\begin{array}{ll}31,623 & 5,604\end{array}\right]$} & 0.2006 & 0.602 & 0.591 \\
\hline$\left[\begin{array}{cc}1000 & 0 \\
0 & 1\end{array}\right]$ & {$\left[\begin{array}{ll}100 & 8,813\end{array}\right]$} & 0.1055 & 0.3165 & 0.311 \\
\hline$\left[\begin{array}{cc}1000 & 0 \\
0 & 4\end{array}\right]$ & {$\left[\begin{array}{ll}100 & 10,3764\end{array}\right]$} & 0.1157 & 0.3471 & 0.341 \\
\hline$\left[\begin{array}{cc}800 & 0 \\
0 & 4\end{array}\right]$ & {$\left[\begin{array}{ll}89,443 & 10,026\end{array}\right]$} & 0,124 & 0,372 & 0,365 \\
\hline$\left[\begin{array}{cc}500 & 0 \\
0 & 4\end{array}\right]$ & {$\left[\begin{array}{ll}70,711 & 9,373\end{array}\right]$} & 0,1442 & 0,4326 & 0,425 \\
\hline
\end{tabular}

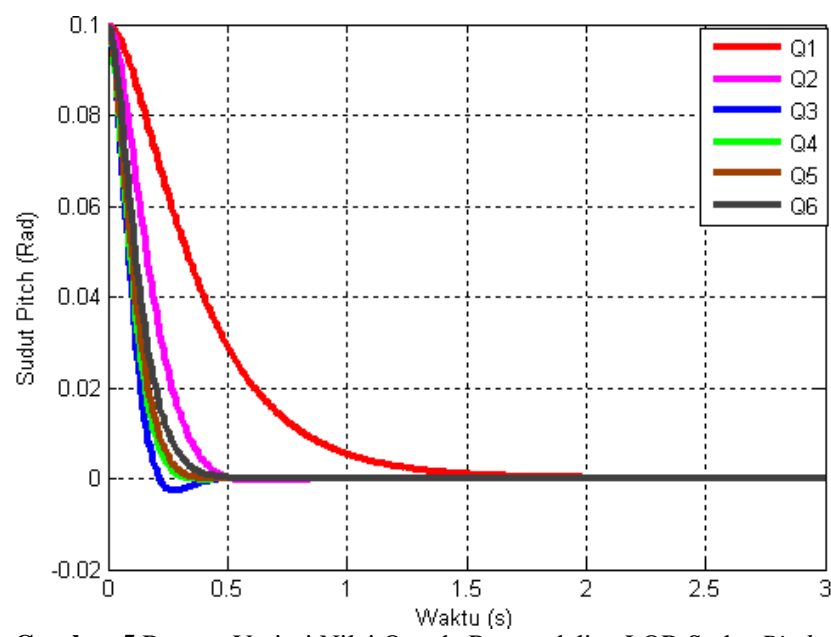

Gambar 5 Respon Variasi Nilai Q pada Pengendalian LQR Sudut Pitch

Dari hasil tersebut dapat diketahui bahwa semakin besar nilai Q, maka akan memperbesar nilai gain feedback, sehingga respon akan semakin cepat mencapai keadaan tunak. Untuk LQR sudut roll dipilih parameter 3 karena lebih cepat menuju keadaan tunak. Sedangkan untuk LQR sudut pitch dipilih parameter 4 dikarenakan pada parameter 3 terdapat overshoot sebesar 0,25\%. Respon gerak rotasi harus memiliki time constant yang lebih cepat karena merupakan inner loop dari pengendalian gerak translasi quadcopter. 


\section{B. Simulasi Pengujian Algoritma Genetika (GA)}

Pengujian GA dilakukan dengan variasi parameter, diantaranya ialah jumlah populasi (P), jumlah generasi (G), rasio seleksi (RS), rasio crossover (RC), dan rasio mutasi (RM). Pada pengujian GA digunakan signal builder yang merepresentasikan lintasan segitiga. Hasil dari tuning GA ditunjukkan pada Tabel 6

Tabel 6 Data Perbandingan Hasil Tuning LQT menggunakan GA

\begin{tabular}{|l|r|r|r|r|r|}
\hline Parameter & GA-1 & GA-2 & GA-3 & GA-4 & GA-5 \\
\hline Populasi & 100 & 100 & 100 & 100 & 100 \\
\hline Generasi & 100 & 300 & 300 & 300 & 300 \\
\hline R.Seleksi & 0,5 & 0,7 & 0,3 & 0,2 & 0,1 \\
\hline R.Crossover & 0,5 & 0,7 & 0,3 & 0,2 & 0,1 \\
\hline R.Mutasi & 0,5 & 0,7 & 0,3 & 0,2 & 0,1 \\
\hline Qx & 714,773 & 714,773 & 711,091 & 701,128 & 700,188 \\
\hline Qy & 756,902 & 756,902 & 703,281 & 700,547 & 700,631 \\
\hline Rx & 0,1026 & 0,1470 & 0,1504 & 0,1575 & 0,1568 \\
\hline Ry & 0,1402 & 0,1275 & 0,1584 & 0,1572 & 0,1579 \\
\hline RMSEx & $1,78 \%$ & $1,95 \%$ & $1,99 \%$ & $1,99 \%$ & $1,99 \%$ \\
\hline RMSEy & $1,89 \%$ & $1,85 \%$ & $1,99 \%$ & $1,99 \%$ & $1,99 \%$ \\
\hline IPx & 68,7717 & 82,2829 & 83,0022 & 84,3374 & 84,0934 \\
\hline IPy & 82,0097 & 78,2114 & 84,0136 & 83,5321 & 83,5227 \\
\hline
\end{tabular}

Respon gerak translasi pada sumbu $\mathrm{X}$ ditunjukkan pada Gambar 6 dan Sumbu Y ditunjukkan pada Gambar 7. Kedua respon tersebut memiliki time lagging sebesar 0,35 detik dan RMSE sebesar 1,99\%.

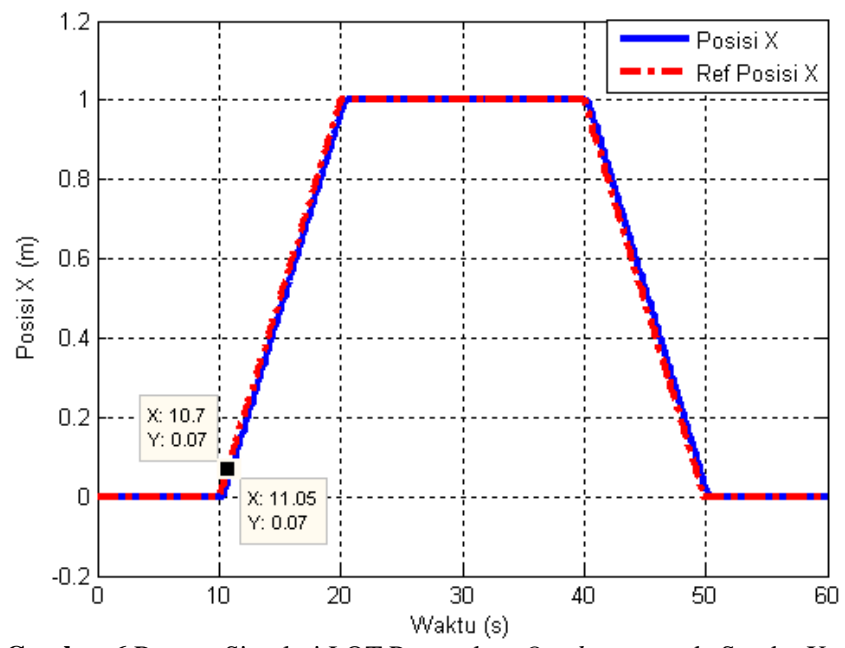

Gambar 6 Respon Simulasi LQT Pergerakan Quadcopter pada Sumbu X dengan Menggunakan Parameter GA-5

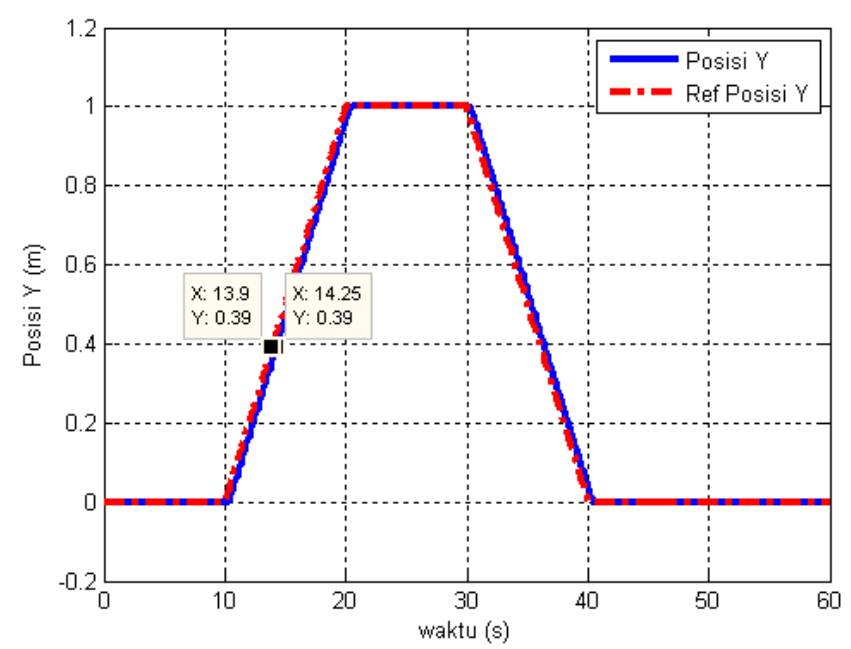

Gambar 7 Respon Simulasi LQT Pergerakan Quadcopter pada Sumbu Y dengan Menggunakan Parameter GA-5

\section{Simulasi Pengujian LQT pada Gerak Lateral}

Gerak lateral atau gerak translasi terdiri dari dua macam yaitu gerak translasi sumbu $\mathrm{X}$ dan gerak translasi sumbu Y. Gerak translasi dapat dilaksanakan jika quadcopter dapat menjaga kestabilan di udara dan selanjutnya bergerak rotasi. Pengujian dilakukan dengan mensimulasikan sistem yang telah dirancang dengan menggunakan signal builder. Hal tersebut dikarenakan untuk men-tracking suatu trajecktory, quadcopter memerlukan proses untuk menuju trajectory tersebut. Pada signal builder dapat dibuat sinyal sesuai dengan keinginan. Sinyal yang dirancang berbentuk sinyal ramp.

Lintasan segitiga dipilih karena memiliki sisi miring, di mana untuk melewati sisi miring tersebut, quadcopter harus melakukan perubahan sudut kurang dari $90^{\circ}$. Jika pergerakan sudut tersebut tidak seimbang, maka akan menyebabkan quadcopter bergerak pada satu sumbu dan dapat menyebabkan quadcopter jatuhRespon gerak lateral quadcopter pada lintasan segitiga terdapat pada Gambar 8 .

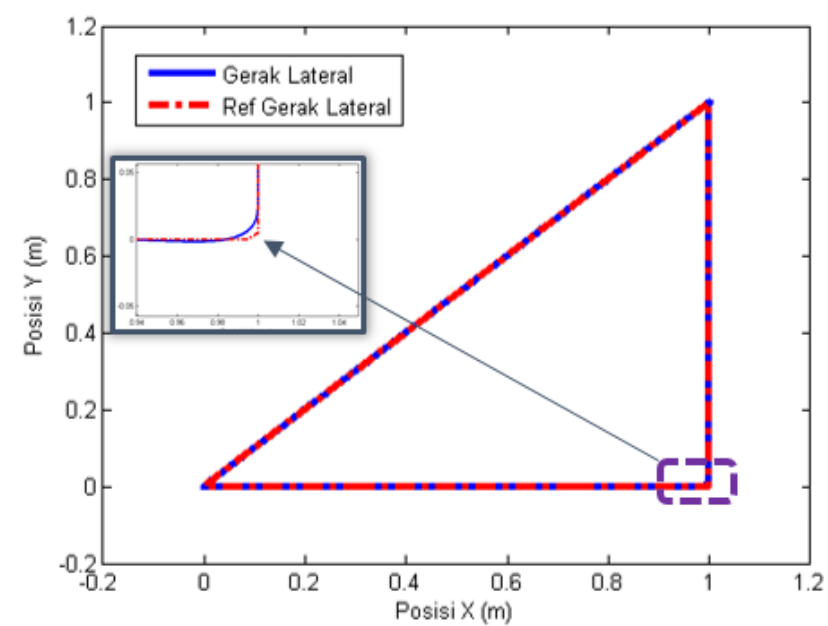

Gambar 8 Respon Simulasi LQT untuk Pengendalian Gerak Lateral Quadcopter pada Lintasan Berbentuk Segitiga tanpa Noise

\section{KESIMPULAN}

Metode tuning GA dapat menggantikan tuning manual (try and error). Dengan parameter tersebut, quadcopter mampu mengikuti trajectory berbentuk segitiga. Hasil tuning GA yang digunakan pada LQT memiliki nilai Qx 700,1884, Qy 700,6315, Rx 0,1568, dan Ry 0,1579. Respon LQT 
tersebut memiliki RMSE pada sumbu X dan Y sebesar 1,99\% serta memiliki time lagging 0,35 detik.

\section{DAFTAR PUSTAKA}

[1]. Haider A. F. Almurib, Premeela T. Nathan, and Nandha Kumar, "Control and Path Planning of Quadrotor Aerial Vehicles for Search and Rescue", SICA Annual Conference, 2011

[2]. Tommaso Bresciani, "Modelling, Identification and Control of a Quadcopter Helicopter", thesis, Department of Automatic Control Lund University, October 2008.

[3]. Argentin, L.M dkk, "PID, LQR, and LQR-PID on a Quadcopter Platform", IEEE Transaction on Aerospace and Electrical Systems, 2013

[4]. Naidu, Subbaram D, "Optimal Control Systems", CRC Press Idaho, Ch.3-4, 2002

[5]. M. Ashari and M. Purnomo, "Linear Quadratic Regulator Design For Modular Matrix Converter Using Genetic Algorithm," IEEE Control Systems Magazines, pp. 175-179, 2011

[6]. Vishal, Ohri Jyoti, "GA Tuned LQR and PID Controller for Aircraft Pitch Control," IEEE 6th India International Conference on Power Electronics (IICPE), 2014 